\title{
Representations of Family Relationships and Generational Conflicts in the Works of British Writers in Diaspora
}

Faten Adi

Department of English

School of Foreign Languages, The University of Jordan

Amman, Jordan

Mahmoud Al-Shetawi

Department of English,

School of Foreign Languages, The University of Jordan

Amman, Jordan

\begin{abstract}
:
This paper aims to discuss representations of family relationships and generational conflicts in the works of British writers in diaspora in the context of British multiculturalism. This study argues that in the context of multiculturalism, generational conflicts ensue between first-generation immigrants and their British-born children for various reasons. While the parents attempt to retain their roots and to belong to their homelands, second-generation children struggle to maintain a balance between submergence into mainstream culture and negotiating flexible identities. The paper also points out that paternal conflicts are the result of the clash of ideologies, emotional alienation, and lack of communication. These concerns will be examined in Hanif Kureishi's The Buddha of Suburbia (1990) and Zadie Smith's White Teeth (2000).
\end{abstract}

Keywords: Family, first-generation immigrants, generational conflicts, Hanif Kureishi, multiculturalism, second-generation children, Zadie Smith.

Cite as: Adi,F.,\& Al-Shetawi, M. (2018). Representations of Family Relationships and Generational Conflicts in the Works of British Writers in Diaspora. Arab World English Journal for Translation \& Literary Studies, 2 (3). DOI: http://dx.doi.org/10.24093/awejtls/vol2no3.5 